Об'єктом дослідження є пиловловлювачі для сухої очистки газу апарати, в яких реалізуються гідродинамічні режими. Переваги використання таких апаратів: робота з газами високої температури, високий ступінь очищення; регулювання процесу очищення газу від пилу за рахунок регулювання витрати вторинного повітря. Серед недоліків пиловловлюваиів слід виділити: високий гідравлічний опір, а також складна експлуатація і установка. Теорія роботи апаратів для сухого очищення газового потоку від пилу ще не вдосконалена $і$ не дає можливості обтрунтованого вибору конструкиії апарату та його основних характеристик. Розглядаеться створення конструкцї̈ пиловловлювача, в якому ступінь очищення газового потоку від пилу досягає 97-98,5\% незалежно від розміру часток дисперсної фази. Цей факт є необхідною умовою для сучасної промисловості. Запропоновано конструкцію гетерогенного реактора для системи газ-тверде з двома потоками, які співударяються. Конструкиія дозволятиме значно інтенсифікувати взаємодію між частками $i$ газовою фазою за рахунок збільшення відносної швидкості фаз при їх руху проти течії. Визначено особливості гідродинаміки реактора, розподілу часу перебування в реакторі $і$ запропонована модель реактора на основі дискретних Марковських процесів. Експериментально встановлено, що ступінь очищення газодисперсного потоку від пилу в запропонованому реакторі може досягати 98 \%. Це можливо в зв'язку з утворенням агломератів за рахунок інтенсивної взаємодії між частинками, які більше розміру часток на вході в реактор в 3-4 рази. Запропонована конструкиія має переваги в порівнянні з відомими промисловими апаратами для сухого очищення газів. Доведено, що в порівнянні з виваженим шаром $і$ гідродинамічними умовами в ииклонах, вихрових камерах запропонований реактор має перевагу з точки зору витрат енергії на подолання опору. Це пов'язано з тим, що в зазначених апаратах велика частка енергї̈ витрачаеться на підтримку частинок в зваженому стані, а також на прокачку повітря через внутрішні пристрої. При експлуатацї запропонованого газоочисного пиловловлювача досягнуті якісні показники, які підтверджують доцільність проведених досліджень $і$ доцільність вибору апарату для сухого очищення газового потоку

Ключові слова: модель реактора, ефективність очищення, пиловий потік, гідравлічний опір
UDC 621.643.532.527.001.5

DOI: $10.15587 / 1729-4061.2018 .133324$

\section{SUBSTANTIATION OF CHOOSING THE DESIGN OF A REACTOR-DUST COLLECTOR WITH TWO COLLIDING FLOWS}

\author{
I. P i t a k \\ $\mathrm{PhD}$, Associate Professor* \\ E-mail: ipitak5@gmail.com \\ V. Sha pore v
}

Doctor of Technical Sciences,

Professor*

O. P i t a k

$\mathrm{PhD}$, Associate Professor

Department of Labour Protection and Environmental**

E-mail: okatip@rambler.ru

N.Ponomarova

$\mathrm{PhD}$, Associate Professor

Department of integrated technologies, processes and devices**

E-mail: n.g.ponomar@gmail.com *Department of Chemical Technique and Industrial Ecology**

**National Technical University «Kharkiv Polytechnic Institute» Kyrpychova str., 2 , Kharkiv, Ukraine, 61002

\section{Introduction}

Known types of reactors for the purification of gas-dispersed flows (cyclones, vortex devices, etc.) have been successfully and widely used in many fields of engineering and chemical technology. Reactors are suitable for those cases when a dispersed phase (solid particles of dust) has dimensions exceeding $300 \mu \mathrm{m}$ and represent a material with a sufficiently high density. However, if a dispersed phase has a low specific gravity, high sail capacity, while the particles are less in size than $20 \mu \mathrm{m}$, then the above-mentioned reactors are almost ineffective for dust collection. This is explained by that the drift force demonstrates itself quite effectively in such devices. This force entrains particles from the wall of a separation chamber into the ejection branch pipe, resulting in the dust accumulating in the conical part of an apparatus.
In addition, these devices have a sufficiently high resistance of up to 1,500 $\mathrm{Pa}$, which demands certain energy costs.

The main objective to improve the purification efficiency is to create a dust collector structure, which would level off the above undesirable effects and ensure a degree of purification of the gas flow from dust at $9798.5 \%$ regardless of particle size of a dispersed phase. This fact is a necessary condition for modern industry.

There is no improvement of the theory of operation of apparatuses for the dry purification of gas flow from dust at present. That does not provide an opportunity for a reasonable choice of the design of an apparatus and its main characteristics. Therefore, the study of flow modes in a dry gas purification apparatus, redistribution of energy at different modes, an influence of characteristics of the gas flow on these parameters is an important task. This would make it 
possible to create an efficient apparatus for the purification of gas flows from dust.

\section{Literature review and problem statement}

A base of modern technology of dry purification of technological and aspiration gas emissions is a number of combined technological schemes of gas purification. Disadvantages of devices and processes of purification of gas emissions at each stage are known [1]. Cyclones of various designs are not capable of collection of dust particles smaller than $20 \mu \mathrm{m}$ [2]. The question about the most effective forms of equipment and its accessories is important [3].

At present, one of the promising areas of research into technology and equipment for dedusting of technological and aspiration gas emissions is development of the theory of centrifugal collection of solid particles from gas emissions. Elaboration of scientific developments in terms of hardware design is also a promising direction [4]. This is necessary to improve efficiency of dry purification of gas emissions.

Papers [5, 6] present the derived mathematical dependences on the choice of conditions for the dry purification of a gas flow from dust and calculation of a dust collection apparatus. There is a determination of a coefficient, which depends on a particle size and varies depending on a change in a fractional composition of dust. The obtained mathematical dependences make possible to determine preliminarily the main design ratios of a dust collector at a given gas flow rate and a given dust collector efficiency. Authors of papers determined speed of dust particles in a vortex flow, as well as basic ratios of structural dimensions of a vortex chamber. Conditions for carrying out a dry purification process play an important role in a choice of structural characteristics of an apparatus. Papers $[7,8]$ proved that we attain qualitative indices during operation of a reconstructed vortex dust collector. And this confirms expediency of the performed studies aimed at investigation of parameters of dry purification apparatuses and expediency of reconstruction of a vortex apparatus. Papers [9-11] consider theoretical bases of dust collection processes and mechanisms in various types of dust collecting apparatuses (cyclones, vortex chambers, vortex tubes, rotoclones). In addition, an effect of hydrodynamic conditions on these processes in pipes for supply of gas-dispersed medium to an apparatus and output branch pipes for purified gas. An angular speed of a flow in a separation chamber and an outlet branch pipe, a character of motion and collision of solid particles before entering a separation chamber plays a significant role in addition to the main parameters that determine rate of precipitation of particles of a solid phase. A magnitude of drift force, which depends on a size of solid particles of physical and chemical properties, also has an effect.

Authors of works [11, 12] established experimentally that under certain modes of the movement of a gas-dispersed flow, before the introduction to a separating part of the apparatus, their agglomeration occurs with an increase in the average size by 3-4 times. It occurs as a result of intense collisions of solid dust particles. This affects an input torque of an amount of gas-dispersion flow movement into a separation chamber. Works also consider similar questions about mechanisms of formation of hierarchical structures of agglomerates in the collision of particles of a solid phase in a moving two-phase flow due to self-assembly of particles into aggregates. A work [12] shows that not only self-assembly occurs, but also aggregation of aggregates. However, it is not always possible to create necessary hydrodynamic conditions to ensure self-assembly of dust-like particles into aggregates in branch pipes for supply of a gas-dispersed flow before introduction to a separation chamber. In many cases, this requires installation of special devices. This leads to an increase in hydrodynamic resistance of apparatuses and, accordingly, energy inputs.

In this regard, it is a matter of interest to create an apparatus (reactor) where would be:

- zones of intensive contact between a gas phase and solid particles (reaction zone);

- a separation zone for separation of gas particles;

- a zone for discharge of separated solid particles;

- a zone of output of purified gas.

Introduction of an additional reaction zone will intensify heat-mass transfer processes between particles and a gas phase greatly. This will happen due to an increase in relative speeds of moving phases with their counter-current motion.

Currently, one of the promising areas of studies on technology and apparatuses of dust removal from technological and aspiration gas emissions is development of the theory of centrifugal collection of solid particles from gas emissions. Also, a promising direction is elaboration of scientific developments in terms of hardware design. This is necessary to improve efficiency of dry purification of gas emissions and to develop a new apparatus for gas purification with maximum purifying efficiency.

\section{The aim and objectives of the study}

The aim of this study is to create a dust collector design, due to which a degree of purification of a gas flow from dust reaches $99.9 \%$ regardless of particle size of a dispersed phase. This fact is a necessary condition for modern industry.

We resolved the following tasks to achieve the objective:

- proposition of the design of a heterogeneous reactor for a gas-solid system with two colliding flows, which will make possible to intensify interaction between particles and a gas phase greatly;

- determination of features of hydrodynamics of a reactor, distribution of stay time in a reactor, and proposition of a model of a reactor based on discrete Markov processes;

- experimental determination of a degree of purification of a gas-dispersed flow from dust in the proposed reactor as more than $90 \%$;

- proving that hydraulic resistance of the proposed structure is much less than the hydraulic resistance of a cyclone.

\section{Investigation of a gas-air flow purification process}

As we know, we can achieve an increase in relative rates of moving phases with their counter-current motion reliably if there is a mode with two colliding gas-dispersed flows realized in a reaction zone $[13,14]$. Based on the above, we created a model of a reactor (dust collector), which includes the listed zones (Fig. 1). 


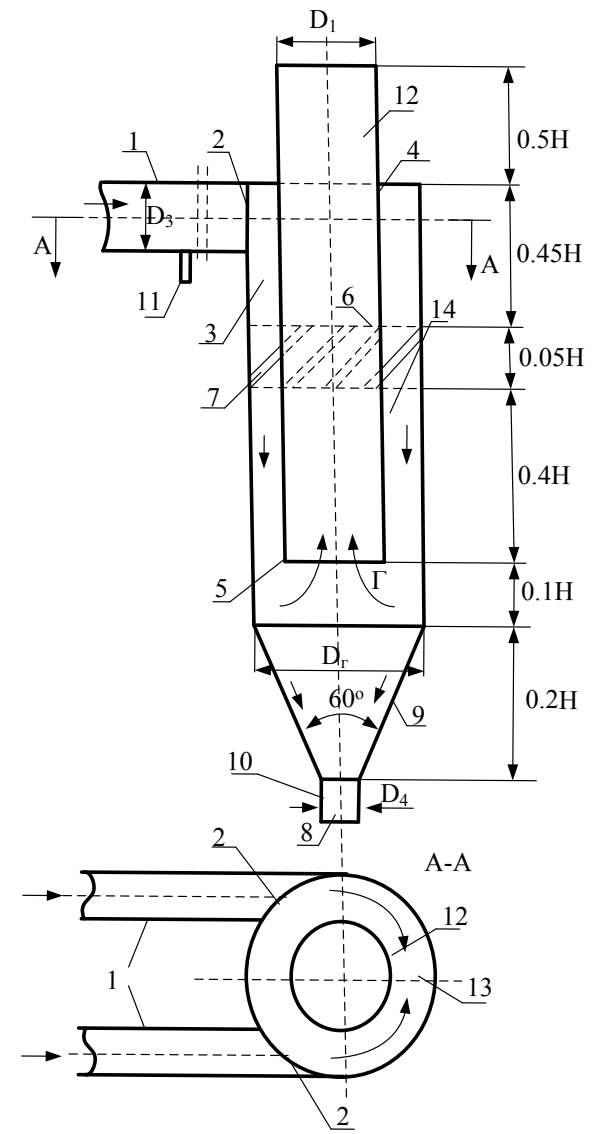

Fig. 1. Multipurpose single-stage reactor-dust collector: $D_{2} / D_{1}=1.5 ; D_{3}=0.25 D_{2} ; D_{4}=0.5 D_{2} ; H / D_{2}=3.2$

The reactor shown in Fig. 1 includes the following elements:

- two gas supply branch pipes 1;

- introduction of gas and dispersed particles into reactor 2;

- annular space 3 between points 4 and 6 , where intense contact occurs between the gas phase and solid particles the reaction zone;

- separating zone for separation of solid particles from gas located between 5 and 6 ;

- twisting planes 7 at an angle of $45^{\circ}$, which forces solid particles to move towards the walls of the reactor radially and then to discharge through opening 8 ;

- the conical part of reactor 9 and the outlet of reactor 8 for discharge of particles;

- gas outlet branch pipe 12;

- the opening for taking of samples of pressure 11 for measuring of differential pressure between the inlet to the reactor and gas outlet 12 .

A dust collector reactor operates as follows. A fan or other pressure device supplies gas through two identical branch pipes 1 located symmetrically in the annular zone at the top of the reactor. The gas-dispersed flow gains speed in branch pipe 1 before it enters the reactor at point 13 preventing solid particles from falling. Two gas flows, which carry solid particles, enter annular space 3 tangentially. The flows collide at point 13, which is symmetric relatively to the flow inputs at points 2. Particles in the two countercurrent flows can behave as follows: they can collide immediately and there will be self-assembly in agglomerates as a result, and they will fall immediately (position 9). In the absence of direct collision or in a weak collision, particles from one gas flow penetrate the other one, they lose speed initially, and then gain up speed by another flow in the direction opposite to the original one. This causes harmonic motion of particles along the perimeter of annular contact zone 3 (known as the Magnus effect), until their speed and direction change with respect to the collision point. Obviously, such a harmonic motion in the reaction zone makes possible to achieve very high sliding speeds. Particles lose their speed due to collisions between themselves and walls of the reactor after several oscillations. They become larger and the gas flow carry them away from active zone 3 . The total gas flow with enlarged particles of the solid phase reaches the separation zone. The separation zone lies between points 5 and 6 , it meets flow twister 7 , which imposes centrifugal forces on particles towards walls of the reactor. As a consequence, they are discharged through opening 8 at conical part 9 . The gas free from particles goes up the branch pipe 12, as in a cyclone. In the "pilot" reactor, we made the upper part, through which branch pipe 12 enters, from a transparent acrylic glass, which made it possible to observe behavior of particles in the collision zone by means of a high-speed camera.

The procedure for conduction of experiments was as follows:

- a description of the mechanism for collection of dust in the apparatus;

- evaluation of overall efficiency in the apparatus;

- consideration of the dominant mechanisms, which influence the process of dust collection;

- establishment of the relationship between the mechanisms of dust collection;

- generalization of the calculated data;

- obtaining calculated dependences.

We used standard methods during the experiments: for measurement of the dust concentration in gases, we used a weighting method for determination of the dust concentration and a counting method for determination of the dispersion composition. We determined dust content by a weight method using the AFA VP-10 filters (made in Ukraine).

We carried out measurements of dust particles and determination of their structure at the discharge from the conical part of the reactor using the electronic microscope UEMV (manufactured in Sumy, Ukraine). Average values of 5 experiments showed that the following formula determines the achieved degree of purification of a gas flow:

$$
\eta=\frac{V_{1} X_{1}-V_{2} X_{2}}{V_{1} X_{1}} \cdot 100 \%
$$

where $V_{1}, V_{2}$ is the volumetric flow rate of initial and purified gas, $\mathrm{m}^{3} / \mathrm{h} ; X_{1}, X_{2}$ is the concentration of suspended particles in dusty and purified gas, $\mathrm{kg} / \mathrm{nm}^{3}$.

When studying the hydrodynamics of the reactor, we measured a pressure drop between the air inlet (or gas-dispersed flow) and its outlet, where it corresponded to atmospheric pressure (points 11 and 12). We carried out measurements at various Reynolds numbers and mass speeds of the gas-dispersed flow. Re numbers varied from 8,000 to 12,000. The concentration of solid particles of the dispersed phase varied in accordance with their mass flow at the inlet to the reactor in the range $25 \div 500 \mathrm{~g} / \mathrm{s}$. The mass ratio of the flow rate of solid particles to the mass flow rate of air was in this case in the range $0.4 \div 3.5$. We calculated measurement re- 
sults obtained as dependences of "Eu" Euler number on "Re" Reynolds number by the diameter of the inlet pipe, that is:

$$
E_{u}=\frac{\Delta P}{\rho_{B} \cdot W_{B}^{2}} ; \quad \operatorname{Re}=\frac{D_{3} W_{B}}{v_{B}} .
$$

\section{Results of experimental study of reactor operation}

The main tasks in carrying out of experimental studies were to determine the capability of reactor operation at various concentrations of solid particles in an incoming gas flow and an effect of Re number on characteristics of a reactor. One of the main tasks was to determine stay time of solid particles in a reactor. Oscillatory motion of particles in a collision zone causes internal recirculation of a passing flow and affects average stay time. In the course of experimental studies, we assumed, as in papers [13, 14], that there are total response values instead of instantaneous values for each experiment, that is, each reading accumulates over a certain time interval $\Delta \mathrm{T}$. We know that if the length of an interval value increases (which corresponds to an instantaneous value) from the zero, sensitivity of readings decreases and, for a certain value, random fluctuations of particles are no longer fixed. As a result, we obtained the same response curves as in the case of " $m$ " single experiments using the standard approach by the equation:

$$
\bar{C}=\frac{\sum_{i=1}^{m} C_{i}}{m},
$$

where $\bar{C}$ is the response curve; $C_{i}$ is the number of labeled particles (or tracer concentration), which corresponds to a separate "i" experiment for a certain $\mathrm{T}$ time.

To select the value of $\Delta \tau$ for each experiment, we used the device shown in Fig. 2.

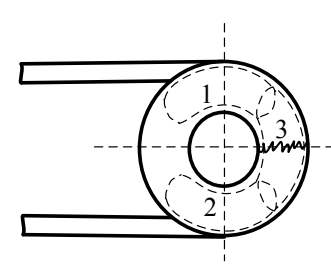

$a$

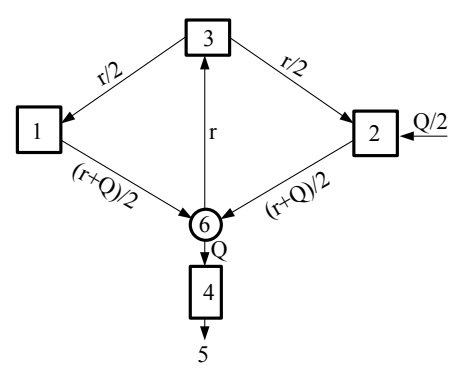

c

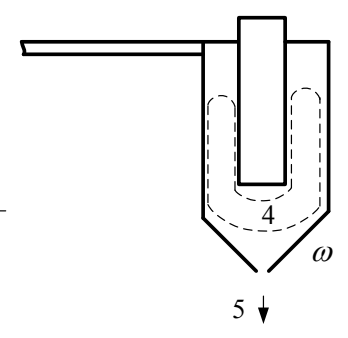

$b$

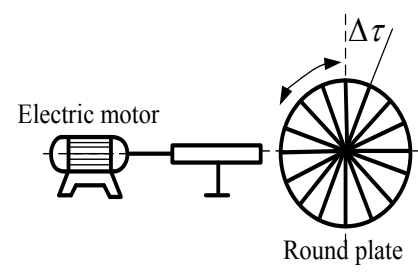

$d$
Fig. 2. Reactor module: $a-$ main zones where mixing and collision of particles occurs; $b$ - lower part of the reactor;

$c$ - model where each volume corresponds to a "stage" in the Markov process; $d$-cycle of particle collision;

1, 2, 3 - zones; 4 -volume of the reactor; 5 - stage of removal of a particle from the system; 6 - collision lines
The device includes a round plate divided into several identical parts (8-16 parts). The plate lies under the opening for discharge of the solid phase from the reactor "c" and rotates due to an electric motor. We obtained different intervals for comparison by changing the rotation speed $(\omega)$, that is, the time required to pass the corner section under the discharge device. To determine distribution of the stay time of particles in the reactor, we represented it schematically by certain zones. There are three main zones where mixing and collision of particles occurs (zones 1, 2, 3, Fig. 2, $a$ ). We considered these zones as complete mixing cells:

- lower part of the reactor Fig. 2, $b$, we described it as a complete displacement reactor without reverse mixing;

- time required for particles to go from zone to zone equal to zero, but a particle can remain in these zones for a finite period of time;

- retention capacity of solid particles " $v$ " is the same for each volume.

The model under investigation (Fig. 2, c) shows that each volume corresponds to the "state" in the Markov process and probability of transition " $P_{i j}$ " is the probability that a particle leaves the volume " $i$ " and then falls into the volume " $j$ ". In this case, presence of the recycle flow " $r$ " corresponds to the flow of particles entering the reactor zone due to harmonic motion when collision line 6 in Fig. 2, $a$ corresponds to the cycle in Fig. 2, $c$. If a particle enters the volume of reactor 4 as in Fig. $2, d$, then it goes to stage 5 , whence it is removed from the system. Thus, the probability " $S_{4}$ " corresponds to such a value that the particle entering the system leaves it at $n=0$ after $n \cdot \Delta \tau$ $(n=1,2 \ldots)$.

The numerical value of $S_{4}(n)$ for $n=1,2$ corresponds to a response of the system to an impulse disturbance after " $n$ " time intervals of $\Delta \tau$ duration. Similarly, the probability value " $S_{5}$ " corresponds to a response of the system to a stepwise disturbance and is the accumulation stage $S_{5}$ " $n$ ", which is the sum of probabilities that tracer particles that are fixed leave the system after time intervals $\Delta \tau ; 2 \Delta \tau \ldots . . ; n \Delta \tau$.

As we can see from the above, we can use a reactor model based on a description of discrete Markov processes to describe distribution curves of the stay time. Equation (2) describes the fact that the sum of probabilities of all states of the system is equal to one.

$$
\sum_{i=1}^{N} S_{i}(n)=1
$$

where $S_{i}(n)$ is the probability of the state, that is, a probability that the system should be in a stage after " $n$ " transitions; $N$ is the number of possible stages for the system transition.

The equation, which describes the discrete Markov process for all states, takes the form:

$$
S(n+1)=S(n) \cdot P
$$

where $S(n)$ is the probability vector; $P$ is the transition matrix, which contains all possible $P_{i j}$.

The probability relates to the geometry of the reactor and is independent on time. We can form a complete transition probability matrix " $P$ ", in which probabilities located diagonally are probabilities that a particle remains in a given volume, of all these " $P_{i j}$ " terms. The probability of entering the " $j$ " volume is in vertical columns, and in horizontal lines - the proba- 
bility of leaving the "j" volume. We can record each transition probability using dimensionless variables in accordance with (1):

$$
v=\frac{V}{4} ; R=\frac{r}{Q} ; \Delta \Theta=\Delta \tau \frac{Q}{V},
$$

where $V$ is the retention capacity of the entire reactor; $v$ is the retention capacity of each volume; $R$ is a recycling ratio; $r$ is the recirculating flow; $Q$ is the flow of gas-dispersed medium at the reactor inlet; $\Delta \Theta$ is a dimensionless time interval.

Initial conditions:

$$
S(0)=S_{1}(0), S_{2}(0), S_{3}(0), S_{4}(0), S_{5}(0)=0.5 ; 0.5 ; 0 ; 0 ; 0 .
$$

Since a particle has the same probability of getting into the system in volumes 1 or 2 , it is equal to 0.5 . In other volumes, the probability of getting into the system is 0 . We can calculate the average stay time for the same $\Delta \tau$ from equation:

$$
\tau=\frac{\sum_{i=1}^{n} C_{i} \tau_{i}}{\sum_{i=1}^{n} C_{i}}
$$

where $n$ is the total number of sections on a round plate (Fig. 2), which contains labeled particles in the sampling device; $C_{i}$ is the number of tracer particles (labeled) in " $j$ " section, and $\tau_{i}=i \cdot \Delta \tau$.

In the course of our study, we used cataphors (super-miniature, glowing glass balls for self-luminous road signs with a diameter of 3-4 $\mu \mathrm{m}$ for better recognition of them in the volume of deposited dust in sections of the sampling device) as tracers. We introduced the tracer into the system for 0.1-0.08 s with a number of particles in each injection of 100 pieces in order to have the actual Dirac function at the reactor inlet. We determined the concentration of labeled particles (tracer) at various time intervals by counting of glowing particles in each section of the device. We chose rotation speed $(\omega)$ of the device such that the entire tracer used in the impulse experiment assembled in 4-5 sections of the rotating device at the minimum speed of the gas flow of air.

We carried out experimental studies at a defining size $D_{3}=40 \mathrm{~mm}$, where air represented the carrier phase $\left(\left(\mathrm{N}_{2}=78.09 \%\right.\right.$ vol., $\mathrm{O}_{2}=20.95 \%$ vol., $\mathrm{CO}_{2}=0.03 \%$ vol, molecular weight $28.98, \rho=1.207 \mathrm{~kg} / \mathrm{m}^{3}$, dynamic viscosity was $208 \mu \mathrm{Pa}$ ). As the dispersed phase, we used: $\mathrm{ZnO}$ (average particle size $d=5 \mu \mathrm{m}$, specific surface by BET (the method of mathematical description of physical adsorption based on the theory of multimolecular (multilayer) adsorption) was $\left.S=8 \mathrm{~m}^{2} / \mathrm{g}, \rho=5,700 \mathrm{~kg} / \mathrm{m}^{3}\right) ; \mathrm{CaO}(d=$ $\left.=10 \mu \mathrm{m}, S=2 \mathrm{~m}^{2} / \mathrm{g}, \rho=2,930 \mathrm{~kg} / \mathrm{m}^{3}\right) ; \mathrm{Ca}\left(\mathrm{OH}_{2}\right)(d=6 \mu \mathrm{m}, S=$ $\left.=15 \mathrm{~m}^{2} / \mathrm{g}, \rho=2,240 \mathrm{~kg} / \mathrm{m}^{3}\right) ; \mathrm{Na}_{2} \mathrm{CO}_{3}\left(d=5 \mu \mathrm{m}, S=13 \mathrm{~m}^{2} / \mathrm{g}\right.$, $\rho=2,160 \mathrm{~kg} / \mathrm{m}^{3}$ ).

Fig. 3 shows the indicated dependences for the carrier medium (air) and a disperse flow with a mass flow rate of solid particles at the inlet of $25 \mathrm{~g} / \mathrm{s}$. We used $\mathrm{ZnO}$ and $\mathrm{CaO}$ as solid particles.

With an increase in gas speed, in the absence of particles in a gas flow, turbulence intensifies and leads to the formation of a vortex motion. Introduction of particles into a moving gas leads to the fact that part of energy converts into kinetic energy of particles instead of increasing of tur- bulence. Therefore, at high gas flow rates, a pressure drop in the presence of particles may be lower than when there are no particles in the flow. Another effect that we observed in the experiment (Fig. 3) is that at high "Re" numbers "Eu" Euler number does not depend on "Re", and, therefore, on hydrodynamic conditions. This phenomenon is important for scaling purposes. In the region of constant "Eu" numbers, forecasting of operating pressures based on laboratory experiments requires observance of geometric similarity between a laboratory apparatus and large-scale equipment. In other words, $\overline{\mathrm{Eu}}=1$ is a necessary condition and it is necessary to respect the size ratio shown in Fig. 1.

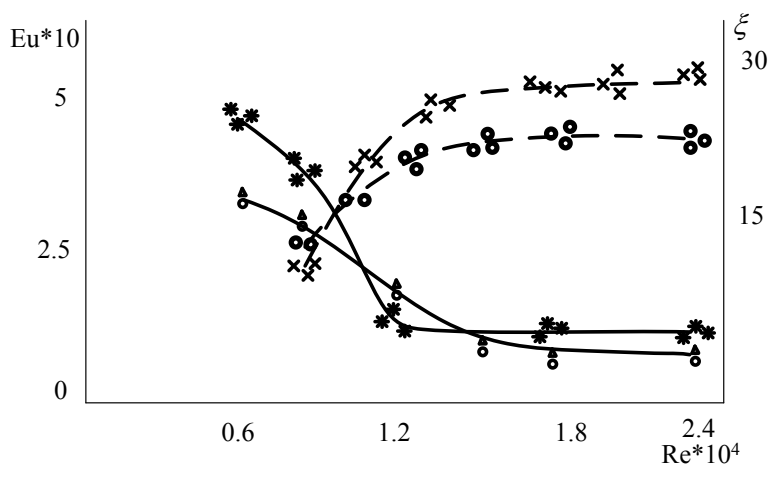

Fig. 3. Dependence of "Eu" number and the coefficient of hydraulic resistance $\xi$ on "Re" value: $\mathbf{x}$, * is carrier medium (air flow), $\mathbf{\bullet}-$ a gas-dispersed flow (o- $\mathrm{CaO}, \Delta-\mathrm{ZnO}$ ),

- $-\xi$ for a dispersed flow

In an area where "Eu" number changes as "Re" function, the following conditions are necessary for scaling: $\overline{\mathrm{Eu}}=1$; $\overline{\mathrm{Re}}=1$ and observing the size ratio. A dash above the designations shows a relationship between a given quantity in a large-scale equipment and a laboratory apparatus.

We studied a response of the system to a different concentration of solid particles in the incoming gas flow to determine working concentrations of solid particles. We carried out experiments for this purpose. At a constant mass speed of particles, the air velocity decreased continuously until the pressure drop began to grow very rapidly at a certain point (14) and the reactor was clogged during the experiment. We established that the ratio of the mass speed of solid particles to the mass velocity of air only $\delta=W_{T} / W_{B}$ depends on a type of particles. When we used particles with a density in the range of $3,000 \div 5,700 \mathrm{~kg} / \mathrm{m}^{3}$ and a relatively low specific surface, the ratio was $\approx 2.0 \div 2.5$. When we used particles with density of $2,100 \div 2,200 \mathrm{~kg} / \mathrm{m}^{3}$ and a relatively high specific surface area, the ratio was $\approx 3.5$. At the indicated ratios, $\Delta=E u_{T} / E u_{B}$, where $E u_{T}$ and $E u_{B}$ are Euler numbers in the presence of particles in the flow and without them tends to infinity and the reactor clogs. The effect of physical and chemical properties of solid particles relates apparently to the mass and heavier particles begin to precipitate intensely in the reaction zone of the reactor and lower with a decrease in the flow rate, which leads to clogging of the reactor.

We presented the results of the pulsed experiment for different rates of flows of solid particles and air, and we determined the dependence of the average stay time on the mass flow rate of air for these cases. Fig. 4 shows the results for three cases of a gas-dispersed flow, which contained $\mathrm{CaO}$ dust concentration equal to $25 \div 70 \mathrm{~g} / \mathrm{nm}^{3}$. 


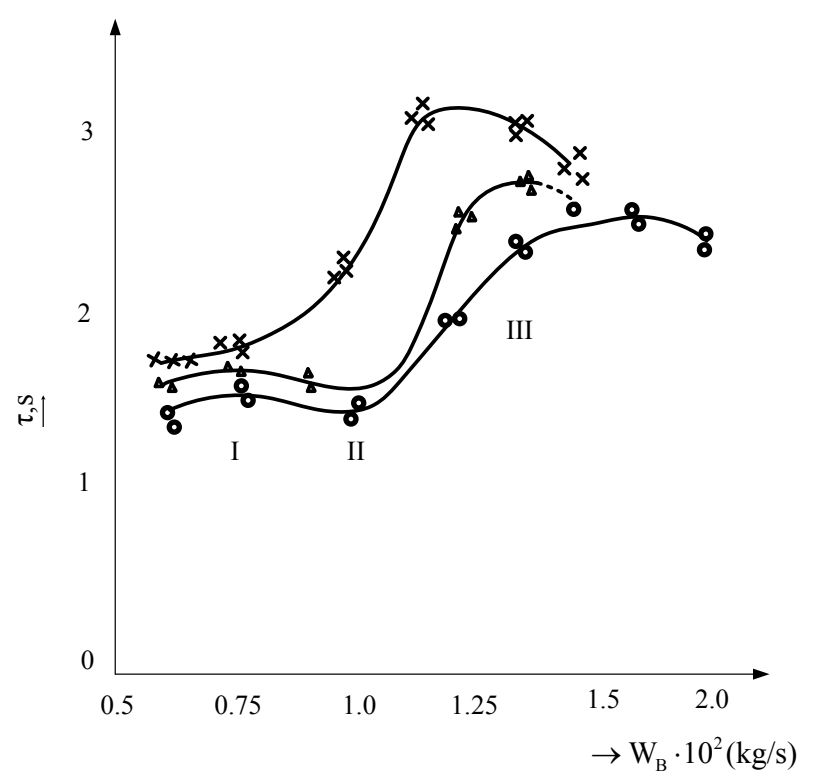

Fig. 4. Dependence of average stay time of dust particles on the air flow rate: $\mathbf{x}, \mathbf{\bullet}, \mathbf{\Delta}-$ experimental dust concentration, respectively: $25,50,70 \mathrm{~g} / \mathrm{nm}^{3}$

We established in the course of experiments at a constant rotational speed of the sampling device that with an increase in " $W_{B}$ " speed, a number of sections of the rotating device required to select the entire tracer increases from 4 to 7 . This result confirms the oscillational motion of particles inside the reactor, which leads to a tracer delay.

We determined a degree of purification of the purified gas flow at the reactor outlet for the experimental conditions shown in Fig. 4 with a use of a gas-dispersed flow with a dust content of $25 \mathrm{~g} / \mathrm{nm}^{3}$ in the form of $\mathrm{CaO}$ and "Re" numbers in the range of $11,000 \div 13,000$ a pilot plant of a new reactor.

The results of measurements showed that " $\eta$ " value is in the range of $97 \div 98.5 \%$, and the discharged dust from the reactor bunker represents itself as agglomerates of the size of $25 \div 35 \mu \mathrm{m}$, while dust particles at the inlet to the reactor were $5 \div 10 \mu \mathrm{m}$ in size.

\section{Discussion of results of studying the gas-air flow purification process}

Steady operation of a reactor can occur at a maximum value of $\Delta$ not more than $1.2 \div 1.5$, that is, at a dust concentration in a gas-dispersed flow, which does not exceed $1.0 \mathrm{~kg} / \mathrm{nm}^{3}$.

The results of measurements showed that " $\eta$ " value is in the range of $97 \div 98.5 \%$, and the discharged dust from the reactor bunker represents itself as agglomerates the size of $25 \div 35 \mu \mathrm{m}$, while dust particles at the inlet to the reactor were $5 \div 10 \mu \mathrm{m}$ in size. That is, it is possible to use the dust removal apparatus considered in this study in all industries where there are exceedances for dust emissions into the atmosphere.

Analysis of the results shown in Fig. 3 shows that when "Re" number is $11,000-20,000$, the lines corresponding to the experiment with the presence of particles in the gas flow cross the curve corresponding only to the airflow. Thus, when operating at high "Re" numbers (and correspondingly at high sliding speeds) a lower energy consumption is required and, accordingly, hydraulic resistance decreases.
The analysis of the conducted studies showed that stable operation of the reactor can occur at a maximum $\Delta$ value of not more than $1.2 \div 1.5$, that is, at a dust concentration in the gas-dispersed flow, which does not exceed $1.0 \mathrm{~kg} / \mathrm{nm}^{3}$. As we know, the dust content in the gas flow, which enters purification, should not exceed $0.2 \div 0.4 \mathrm{~kg} / \mathrm{nm}^{3}$ for modern cyclone constructions [15].

1. The first zone, where " $r$ " increases and reaches a maximum with an increase in the flow rate. But it is a function only " $W_{B}$ "; $r=f\left(W_{B}\right)$ in this " $r$ " zone.

2 . The second " $r$ " zone reaches a minimum before the beginning of rapid growth to the second maximum. In this zone, two factors affect $r$ value, when " $W_{B}$ " grows, it causes the oscillational motion of particles inside the reactor, which in turn causes an increase in a number of particles entering the collision zone. However, an increase in a number of particles leads to a greater probability of their collision and enlargement, as well as the subsequent immediate discharge. Therefore, in the second zone, oscillations and collisions affect " $\tau$ " in the opposite direction and $r=r\left(W_{B}, \eta_{T}\right)$, where $\eta_{T}$ is the number of solid particles.

3. In the third zone, particle density is so large that the average stay time decreases due to collisions, and oscillations play no significant role in determination of its value. $r=r\left(\eta_{T}\right)$ in this region.

Efficiency of apparatuses decreases with an increase in dimensions due to uneven distribution of a flow in the operation volume of an apparatus and the phenomenon of the scale effect. Therefore, studies on enlarged models give more reliable results, which we can use directly in the design of industrial devices.

We proved that when an airflow rate increases, purification efficiency decreases. Therefore, it is necessary to take into account the airflow rate and design features of the designed devices to achieve maximum purification efficiency.

\section{Conclusions}

1. We proposed the design of a heterogeneous reactor for a gas-solid system with two colliding flows. This makes it possible to intensify the interaction between particles and the gas phase greatly by increasing the relative phase speed at their counter-current motion.

2. We determined specific features of the hydrodynamics of a reactor, distribution of stay time in a reactor, and proposed a model of a reactor based on discrete Markov processes.

3. We established experimentally that a degree of purification of a gas-dispersed flow from dust in the proposed reactor can reach $98 \%$. This is possible because of formation of agglomerates due to intensive interaction between particles that are larger than the particle size at the reactor inlet by $3-4$ times.

4. We proved that in comparison with the suspended layer and hydrodynamic conditions in cyclones and vortex chambers, the proposed reactor has an advantage in terms of energy consumption for overcoming of resistance. Mentioned devices spend a large proportion of energy to maintain particles in a suspended state, as well as to pump air through internal devices. Thus, resistance of the proposed design under steady-state mode is $400-600 \mathrm{~Pa}$. 


\section{References}

1. Modrzycka A., Winczek J. Ekologia i ochrona środowiska w budownictwie // Edukacja - Technika - Informatyka. 2016. Vol. 18, Issue 4. P. 177-182. doi: 10.15584/eti.2016.4.22

2. Suranani S., Kumar S., Sridhar S. New frontiers in chemical energy and environmental engineering // Environmental Science and Pollution Research. 2016. Vol. 23, Issue 20. P. 20053-20054. doi: 10.1007/s11356-016-7565-5

3. Environmental management systems in the construction industry - a review / Campos L. M. S., Trierweiller A. C., De Carvalho D. N., Šelih J. // Environmental engineering and management journal. 2016. Vol. 16, Issue 2. P. 453-460.

4. Aslamova V. S., Zhabey A. A. Avtomatizirovannaya sistema issledovaniya ciklonov i skrubberov // Izvestiya Tomskogo politekhnicheskogo universiteta. Inzhiniring georesursov. 2010. Vol. 316, Issue 4. P. 71-76.

5. Justification of the calculation methods of the main parameters of vortex chambers / Pitak I., Shaporev V., Briankin S., Pitak O. // Technology audit and production reserves. 2017. Vol. 5, Issue 3 (37). P. 9-13. doi: 10.15587/2312-8372.2017.112782

6. Mines R. O. Environmental engineering: principles and practice. Wiley-Blackwell, 2014. 662 p.

7. Analysis of the sanitary purification of gas emissions from dust in the lime manufacture / Pitak I., Briankin S., Pitak O., Shaporev V. // EUREKA: Physics and Engineering. 2017. Issue 5. P. 65-72. doi: 10.21303/2461-4262.2017.00435

8. Study of functioning of a vortex tube with a two-phase flow / Shaporev V., Pitak I., Pitak O., Briankin S. // Eastern-European Journal of Enterprise Technologies. 2017. Vol. 4, Issue 10 (88). P. 51-60. doi: 10.15587/1729-4061.2017.108424

9. Baltuk V. A., Melnikov O. B., Mirus O. V. Zalezhnist efektyvnosti pylovlovliuvannia vidtsentrovo-inertsiynykh aparativ vid konstruktsiyi bunkera // Promyslova hidravlika i pnevmatyka. 2011. Issue 2 (32). P. $44-47$.

10. Singh G., Saini D., Chandra L. On the evaluation of a cyclone separator for cleaning of open volumetric air receiver // Applied Thermal Engineering. 2016. Vol. 97. P. 48-58. doi: 10.1016/j.applthermaleng.2015.10.087

11. Entropic Invariants of Two-Phase Flows / E. Barsky (Ed.). Azrieli College of Engineering, Jerusalem, 2015. 266 p. doi: 10.1016/ c2013-0-23121-4

12. Tret'yakov Yu. D., Slin'ko M. G., Melihov I. V. Materialy seminara po probleme «nelineynaya dinamika himicheskih reakciy, processov i reaktorov. Hronika» // Teoreticheskie osnovy himicheskoy tekhnologii. 2007. Vol. 41, Issue 2. P. 237-238.

13. Zuykov A. L. Gidravlicheskoe modelirovanie kontrvihrevyh techeniy // Vestnik MGSU. 2014. Issue 6. P. 114-125.

14. Metody uskoreniya gazodinamicheskih raschetov na nestrukturirovannyh setkah / Volkov K. N., Deryugin Yu. N., Emel'yanov V. N., Karpenko A. G., Kozelkov A. S., Teterina I. V. Moscow: FIZMATLIT, 2014. 536 p.

15. Cyclones and fabric filters dusts from secondary aluminium flue gases: a characterization and leaching study / Tsakiridis P. E., Oustadakis P., Moustakas K., Agatzini S. L. // International Journal of Environmental Science and Technology. 2016. Vol. 13, Issue 7. P. 1793-1802. doi: 10.1007/s13762-016-1014-3 